\title{
User innovation and the market
}

Citation for published version (APA):

Gault, F. (2011). User innovation and the market. UNU-MERIT, Maastricht Economic and Social Research and Training Centre on Innovation and Technology. UNU-MERIT Working Papers No. 009 https://doi.org/10.2139/SSRN.1949182

Document status and date:

Published: 01/01/2011

DOI:

10.2139/SSRN.1949182

Document Version:

Publisher's PDF, also known as Version of record

\section{Please check the document version of this publication:}

- A submitted manuscript is the version of the article upon submission and before peer-review. There can be important differences between the submitted version and the official published version of record.

People interested in the research are advised to contact the author for the final version of the publication, or visit the DOI to the publisher's website.

- The final author version and the galley proof are versions of the publication after peer review.

- The final published version features the final layout of the paper including the volume, issue and page numbers.

Link to publication

\footnotetext{
General rights rights.

- You may freely distribute the URL identifying the publication in the public portal. please follow below link for the End User Agreement:

www.umlib.nl/taverne-license

Take down policy

If you believe that this document breaches copyright please contact us at:

repository@maastrichtuniversity.nl

providing details and we will investigate your claim.
}

Copyright and moral rights for the publications made accessible in the public portal are retained by the authors and/or other copyright owners and it is a condition of accessing publications that users recognise and abide by the legal requirements associated with these

- Users may download and print one copy of any publication from the public portal for the purpose of private study or research.

- You may not further distribute the material or use it for any profit-making activity or commercial gain

If the publication is distributed under the terms of Article $25 \mathrm{fa}$ of the Dutch Copyright Act, indicated by the "Taverne" license above, 


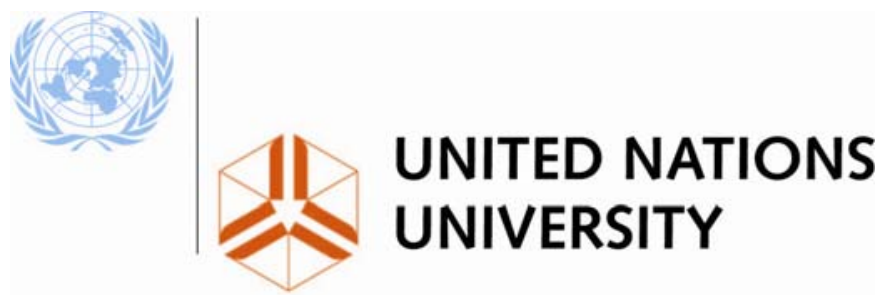

UNU-MERIT

\section{\#2011-009}

User innovation and the market

By Fred Gault

United Nations University - Maastricht Economic and social Research and training centre on Innovation and Technology Keizer Karelplein 19, 6211 TC Maastricht, The Netherlands

Tel: (31) (43) 388 4400, Fax: (31) (43) 388 4499, email: info@merit.unu.edu, URL: http://www.merit.unu.edu 


\section{UNU-MERIT Working Papers}

\section{ISSN 1871-9872}

Maastricht Economic and social Research and training centre on Innovation and Technology, UNU-MERIT

UNU-MERIT Working Papers intend to disseminate preliminary results of research carried out at the Centre to stimulate discussion on the issues raised. 


\title{
User Innovation and the Market
}

\author{
Fred Gault \\ UNU-MERIT, Maastricht, the Netherlands \\ and the Tshwane University of Technology (TUT) \\ Institute for Economic Research on Innovation (IERI), Pretoria, South Africa.
}

\begin{abstract}
This paper proposes a way of including in official statistics consumers as user innovators who modify or develop products for their own use. The issue addressed is the role of the market in the definition of innovation in the OECD/Eurostat Oslo Manual and the exclusion by the definition of consumers who modify or develop products and then freely reveal the knowledge gained to others. A modest proposal is made for a change to the definition which also has implications for the measurement of innovation in the public sector. The policy implications of user innovation by consumers and by firms are considered along with the importance of including consumer user innovation in official statistics. The paper ends with a programme for future work.
\end{abstract}

\section{JEL Codes}

H00, O33

\section{Key words}

User innovation, consumer innovation, public sector innovation, official statistics 



\section{Introduction}

This paper proposes a way of including in official statistics consumers as user innovators who modify or develop products. Official statistics are those produced by or for governments for official use. In this case the use would be the provision of evidence in support of the development of innovation policy, including that dealing with user innovation by firms and by consumers. The definition of innovation, which governs official statistics in member states of the European Union and member countries of the Organization for Economic Co-operation and Development (OECD) is given in the Oslo Manual (OECD/Eurostat 2005).

According to the Oslo Manual innovation is a market phenomenon. A new good or service, or process, is an innovation only if it is connected to the market. This connection works for firmbased innovation as the firm exists to sell products (goods or services) to the market. As part of its business strategy, a firm will launch a new product on to the market or use a new process to move products to market. Consumers are another matter. They do not exist to sell products to the market.

\subsection{User Innovation}

A subset of the activity of innovation just described is user innovation, the subject of this paper. Users are firms or individual consumers that expect to benefit from using a good or a service (von Hippel, 2005:3). User innovators change the good or service to enhance the benefit provided but that benefit must, according to the Oslo Manual, have a link to the market. An example of user innovation is the modification of a production process in a firm, by the firm itself, to improve it. This benefits the firm and helps to move the products of the firm to market. It is a user innovation as the firm uses process technology, it does not sell it as a product. It is the connection to the market that qualifies the process improvement as an innovation and in this case a user innovation. A second example is a consumer who modifies a good or service or develops one. In official statistics, guided by the Oslo Manual, this consumer activity would not be classified as user innovation unless connected to the market. This sets apart user innovation by consumers from user innovation by firms.

There are two barriers to understanding user innovation by consumers, and its impact. The first is the definition of innovation which is the focus of this paper and the second is the absence of social surveys that capture the activity of consumers modifying or developing goods or services to suit their needs. This second barrier is being addressed by work in the UK and in Finland. However, the conceptual question that has to be addressed is the nature of user innovation, especially on the part of consumers. The absence of social survey data and the present definition explain the absence of consumer user innovation in official statistics. This absence deprives policy analysts of knowledge about the creative activity of the population as well as its link to the business sector.

The paper reviews the evidence for user innovation in firms and by consumers and develops a case for knowing more about these activities. The first part of the case is the establishment of the 
magnitude of user innovation, arguing that the size of the activity suggests that user innovation should have a more prominent place in innovation policy. The second part of the case has to do with evidence that user innovators are more inclined to share the knowledge gained in creating their innovation. Sharing, in the case of consumer innovation, renders the activity invisible to official statistics. In the case of the firm, sharing with other firms could result in a change in innovation statistics, if another firm takes the knowledge shared and changes its production process. In both cases, there are questions raised about intellectual property law and the economic consequences of sharing knowledge.

Part of the solution to the problems identified is a modest proposal for a change in the market concept to accommodate the sharing, freely, of the knowledge gained from user innovation. The paper concludes with recommendations for work by official statisticians who produce indicators of innovation, and user innovation, and by the policy analysts who use the indicators.

\subsection{Distinguishing user innovation from user-driven innovation and users as collaborators}

Before going on, the distinction is made between user innovation, user-driven or user-centred innovation, and users as collaborators in innovation ${ }^{1}$. A user innovator benefits from solving a problem. In the case of user-driven innovation, users are a source of information for the producers of goods or services purchased by the user. These users provide feedback to the producer through service agreements, complaints, upgrade requests, through contact with sales and marketing staff and through the use of social media and crowd sourcing (Greene, 2011). Users are a key input to innovation, a finding that is one of the most robust in innovation surveys. Users can also collaborate with producers to generate new or significantly improved products or processes. In innovation surveys, they rank high on the list of collaborators chosen by firms. Ogawa and Piller (2006) have shown that producers involve users in product development to minimize the risks inherent in new product development. The users described in their work cover the range from a source of information, to collaborators, and to user innovators that have produced their own products. An example of facilitated user involvement in the innovation process is the Living Lab (livinglabs.mit.edu or www.openlivinglabs.eu/livinglabs).

While users play many roles in innovation, in this paper only their role as a user innovator is considered. The discussion starts in Section 2 with user innovation in the firm, and moves on to consumers as user innovators in Section 3. That leads to the question of definition in Section 4 and thoughts on the place of the market in Section 5. This brings in a discussion of innovation in the public sector and the definition of innovation. Section 6 turns to policy issues related to user innovation and especially to consumers as user innovators. Section 7 is an agenda for future work.

\section{User Innovation in Firms}

\footnotetext{
${ }^{1}$ These distinctions are elaborated in Chapter 3 of Ministry of Employment and the Economy (2010).
} 
There are two approaches to measuring user innovation by firms. The first is the Community Innovation Survey (CIS) and CIS-like surveys that are conducted to provide information on the presence of the activity of innovation. The second comes from technology use surveys that ask the user if any of the technologies specified in the survey were adopted and modified or adopted by developing the technology by the respondent. Responses for both approaches will show that user innovation is a common occurrence.

\subsection{Innovation Surveys}

In CIS and CIS-like surveys there are questions on process innovation to determine whether the firm is a process innovator. If the response is positive, there is a follow-up question:

Q1: Who developed these process innovations?

1. Mainly your enterprise or enterprise group

2. Your enterprise together with other enterprises or institutions

3. Mainly other enterprises or institutions

A positive answer to the first question suggests the presence of user innovation. A positive response to the second question might also indicate user innovation if the enterprise is driving the collaboration. The third question is a case of adoption of the process from outside the firm. So long as the process adopted is 'new to the firm' it is a process innovation at the lowest level of novelty permitted in the Oslo Manual, but it is not user innovation. Responses to these questions vary by country, but they decline in magnitude from the first to the third. For example the Canadian Innovation Survey for 2005 for manufacturing found that the rates for process innovators were (64 per cent, 29 per cent, and 7 per cent). As the same survey found that 50 per cent of Canadian manufacturing firms were engaged in process innovation (Uhrbach 2009), at least 32 per cent of the population of manufacturing firms engaged in user innovation. That is an example of evidence of user innovation appearing in official statistics.

\subsection{Technology Use Surveys}

Surveys of the use and planned use of technologies and practices are well established (Gault 2010) and tend to be done in response to a policy concern about the need to adopt more of the relevant technologies to make the country more competitive. The first such survey done at Statistics Canada was for 1987 (Statistics Canada 1987). With interest in user innovation stimulated by von Hippel (1988), questions on the modification of the adopted technologies, or on adoption by developing the technologies were added to subsequent surveys. An example is the survey of Advanced Manufacturing Technologies (AMTs) conducted for 1998 (Statistics Canada 2001). It was based upon a survey of the use and planned use of 26 AMTs. The sample consisted of Canadian manufacturing establishments (plants) with at least 10 employees. Among other questions, it collected data on the adoption, modification and development of 26 specific technologies that had been selected as advanced manufacturing technologies (AMTs) at the time of the survey - technologies such as material-cutting with the use of laser energy or water jets rather than traditionally-used physical cutting tools (Arundel and Sonntag, 2001). A key finding was that 46 percent of the surveyed manufacturers bought AMTs 'off the shelf' only. Twenty-six 
percent, however, modified the AMT equipment they purchased, and 28 per cent developed their own specific technologies because there was no market supply.

In 2007, Statistics Canada conducted another survey of the use and planned use of advanced manufacturing technology and asked about adoption by in-house modification or development (Statistics Canada 2008a). While the lists of technologies vary between the 1998 survey and that of 2007, the propensity of plants in manufacturing to use or plan to use at least one of the technologies in the list had increased from 76 per cent in 1998 to 92 per cent in 2007. The propensity to modify or develop at least one of the technologies for the same two surveys was 26 per cent and 28 per cent in 1998 (Arundel and Sonntag 2001) and 21 per cent and 22 per cent in 2007 (Schaan and Uhrback 2009). While this appears to be a declining trend, when adjusted for the increased propensity to adopt at least one advanced manufacturing technology between 1998 and 2007, the fraction of plants adopting or planning to adopt through modification or development has remained more or less the same: about 20 per cent of manufacturing plants in Canada are adopting advanced technologies by purchasing and modifying them, and a comparable proportion is adopting by developing the technology needed in the absence of a suitable product available on the market.

The 2005 Innovation Survey (Uhrbach 2009) found that 32 per cent of the population of Canadian manufacturers engaged in user innovation (Answered Q1 by indicating option 1), with up to an additional 15\% that could be user innovators through collaboration (Q1, option 2). The surveys of technology user for 1998 and 2007 found that about 20 per cent of manufacturing firms modified technologies and about 20 per cent adopted technologies by developing them. In the classifications used in the technology use surveys, a developer could also engage in modification of other technologies, and purchase off the shelf technologies whereas a modifier could modify and could purchase off the shelf technologies. This suggests that the estimate for user innovation from the technology surveys is under bounded by 40 per cent and that the findings from the technology surveys and the innovation survey are comparable.

More recently, the Survey of Innovation and Business Strategy 2009 (Statistics Canada 2010) was released and it included a section on technology adoption. The survey covered 67 industries but for manufacturing, 33.7 per cent of the population modified their technologies and 20.5 per cent adopted technologies by developing them. The combined figure suggests an under bound of 54 per cent of the population of manufacturing firms with 20 or more employees are engaged in user innovation. For all industries surveyed, 83.4 per cent of firms purchased off the shelf technologies, but this figure includes the firms that adopted technologies by developing them, and also modified technologies, and purchased off the shelf technologies, as well as those firms that modified technologies and purchased off the shelf technologies. More results from this survey will follow later in 2011.

The presence of the activity of user innovation is also confirmed by a recent business survey conducted by the National Endowment for Science, Technology and the Arts (NESTA) in the UK. The telephone survey collected data from 1,004 firms with between 10 and 250 employees in 15 industry sectors. (Flowers et al. 2010). It found that 15 per cent of the sample modified or developed process technologies, including software, in the three year of the reference period. The 
results also showed a size dependence, found in other surveys, which would account for the finding of 15 per cent being less than the findings from the Canadian surveys just discussed that had no upper bound on firm size. The conclusion from the Canadian and UK surveys just presented is that user innovation is a significant activity in firms.

When this is combined with a predisposition of user innovators to share their knowledge at no cost (Gault and von Hippel 2009, de Jong and von Hippel 2009 and von Hippel 2005), there are immediate implications for innovation policy and for intellectual property law (Baldwin and von Hippel 2009). These will be discussed in Section 6.2.

While the results reported from the Canadian surveys were for the manufacturing sector, the NESTA survey confirmed user innovation in 15 sectors. In addition, case studies have found user innovation in libraries, hospitals, and firms producing computer aided design software and apache operating system server software (von Hippel 2005:20). Additional evidence in support of the observation that user innovators have a tendency to freely reveal their knowledge is also provided in von Hippel (2005:77). The purpose of this section was to demonstrate that the magnitude of user innovation can be found not just in case studies but in official statistics which provide robust population estimates that can support international comparisons and lead to a public policy debate.

\section{User Innovation by Consumers}

User 'innovation' by consumers has also been identified in the literature and reviewed in von Hippel (2005). Innovation is put in inverted commas to indicate that, for statistical purposes not all of the activities engaged in by consumers, however creative, would be classified as innovation for the purpose of official statistics. This question is the subject of the following section. The purpose of this section is to establish the magnitude of the phenomenon to demonstrate that it merits policy consideration and to raise the importance of conducting surveys of consumers to gather information on their propensity to develop or change goods or services.

A leading contribution to filling the social survey gap has been undertaken by the NESTA. NESTA conducted a consumer survey and a business survey to probe the occurrence of user activities. The consumer survey, with a sample of 2,019 consumers, older than 15 , found that " 8 per cent of UK consumers created or modified one of more of the consumer products they use to better address their needs" (Flowers et al. 2010). This is a significant number and 2 per cent reported that their products had been taken up by other users or adopted and manufactured by producers (von Hippel, de Jong and Flowers 2010).

In Finland, TEKES, the Finnish funding agency for Technology and Innovation, supported by the Ministry of Employment and the Economy (Ministry of Employment and the Economy 2010), is launching surveys of consumers to identify the extent to which they develop or modify consumer products. The original discussion that led to this paper took place in Finland when it became clear that much of what is claimed as user innovation is ruled out by the definition of 
innovation used to support the gathering, interpretation and diffusion of data for official statistics.

\section{The Definition of Innovation and User Innovation}

This Section examines the definition of innovation in the Oslo Manual and its implications for user innovation by firms and by consumers. In Section 5, the discussion is extended to the public sector.

\subsection{The Definition Used for Official Statistics}

For statistical purposes, the definition of innovation is taken from the Oslo Manual (OECD/Eurostat 2005). It is the following.

An innovation is the implementation of a new or significantly improved product (good or service), or process, a new marketing method, or a new organizational method in business practices, workplace organization or external relations (OECD/Eurostat 2005, para. 146).

'Implementation', used in the definition, links the activity of innovation to the market.

A common feature of an innovation is that it must have been implemented. A new or improved product is implemented when it is introduced on the market. New processes, marketing methods or organizational methods are implemented when they are brought into actual use in the firm's operations (OECD/Eurostat 2005, para. 150).

For the Oslo Manual definition, an innovation does not have to be successful and it does not have to be good. Monitized debt was, for a short time, a very successful new or significantly improved product delivered to the market by the U.S. financial services industry, but it was not good for the world economy. The iPod is an innovation that has changed lives and continues to do so. Some products do not sell once they are on the market and the firm fails. The only requirement in the Oslo Manual definition is that the product be brought to market and, implicitly, that the process innovations (transformation of inputs to products and their delivery to the market, industrial organization and use of business practices, and market development) help move the product through the firm to the market.

In earlier sections the magnitude of user innovation has been established, along with the tendency to freely reveal the knowledge that results from producing the user innovation. The discussion now turns to how the user innovation appears in official statistics using the Oslo Manual definition for innovation. Table 1 provides a summary of the present situation.

\subsection{Firms Changing or Creating their Processes}


First consider user innovation in the firm. The firm modifies its process and it does this for its own benefit. Here, process refers to all of the possibilities provided in the Oslo Manual definition. For a firm, the benefit will involve producing the products of the firm more inexpensively, or moving them more efficiently to the clients, or expanding the client base, or some combination of these benefits. Doing this makes the firm a user innovator. The firm uses processes. It does not sell its processes. In modifying an existing process or adopting a new process by developing it, the firm creates knowledge. That knowledge may or may not be protected by an intellectual property instrument and it may or may not be shared.

Table 1: User innovation in official statistics*

\begin{tabular}{|l|l|l|}
\hline $\begin{array}{l}\text { Knowledge } \\
\text { transfer }\end{array}$ & \multicolumn{1}{|c|}{$\begin{array}{c}\text { Firm modifies or develops a } \\
\text { process } \\
\text { (a) }\end{array}$} & $\begin{array}{l}\text { Consumer modifies or develops a } \\
\text { product } \\
\text { (b) }\end{array}$ \\
\hline 1. To a producer & $\begin{array}{l}\text { Product innovation (user } \\
\text { innovation) }\end{array}$ & $\begin{array}{l}\text { Product innovation (user } \\
\text { innovation) }\end{array}$ \\
\hline $\begin{array}{l}\text { 2. To its self as } \\
\text { new firm or new } \\
\text { product line }\end{array}$ & $\begin{array}{l}\text { Product innovation (producer } \\
\text { innovation) }\end{array}$ & $\begin{array}{l}\text { Product innovation } \\
\text { (producer)/entrepreneur }\end{array}$ \\
\hline 3. To peer group of & $\begin{array}{l}|c| \\
\text { Process innovation (user } \\
\text { innovation) in the originating } \\
\text { firm } \\
\text { Process innovation by adopting } \\
\text { firms (Option 3, Q2) }\end{array}$ & No innovation \\
\hline $\begin{array}{l}\text { 4. Not } \\
\text { transferred }\end{array}$ & $\begin{array}{l}\text { Process innovation (user } \\
\text { innovation ) in the originating } \\
\text { firm }\end{array}$ & No innovation \\
\hline
\end{tabular}

* The activities in Table 1 are found in business surveys, such as the CIS, for all cases in Col. (a) and for cases 1(b) and 2(b). A social survey is required to find the activities in cases 3(b) and 4(b).

Table 1 summarizes the options for the transfer of the knowledge, which may be transferred for a fee or license payment, or transferred for free. In the first case, 1(a), the firm transfers the knowledge to the producer in the hope of getting a better process in the next released by the producer, or some related benefit. If the producer uses the knowledge, it would be recorded as a product innovation in a CIS survey and the response would, in principle, indicate that the product innovation arose through the third option in the follow up question, Q2.

Q2: Who developed these product innovations?

1. Mainly your enterprise or enterprise group

2. Your enterprise together with other enterprises or institutions

3. Mainly other enterprises or institutions

This would make the respondent a product innovator as a result of user innovation. 
In the second case, 2(a), the firm decides to develop another product line, or to set up a separate firm to sell the new process. In this case, the firm or the spin-off is a product innovator, but the answer to Q2 is the first option.

In the third case, 3(a), the firm is part of a community of practice that shares its knowledge gained from solving process problems. The knowledge may be shared for a fee or freely revealed, but it is shared. The originating firm is a user innovator of process innovation (first option in response to Q1). The members of the community of practice may or may not make use of the knowledge that has been transferred. If they do, they are process innovators, but they would respond to the third option of Q1. Depending upon the size of the community of practice, the use of the shared knowledge could have a significant effect on the statistic describing the propensity to innovate in the industry.

In the final case, 4(a), the originating firm does not share the knowledge. It is still a user innovator because its innovation is connected to the market by the selling of the products of the firm. While there are economic benefits to sharing knowledge, freely (Baldwin and von Hippel 2010), these are lost, but the user innovation remains.

\subsection{Consumers Creating or Changing Goods or Services}

As mentioned earlier, consumers are individual end users that do not produce or sell goods or services. However, they do modify the goods or services they acquire and they also create new goods or services (von Hippel 2005). The extent to which this activity is user innovation, according to the Oslo Manual definition, is summarized in Table 1.

The consumer may take the prototype good or service back to the producer and ask that an improved product be produced (1(b)). If this happens, it is the same as if a firm had done it. The firm becomes a product innovator and selects the third option in Q2 which makes this a user innovation.

The consumer may start a firm (2(b)) and, as with the case 1(b), the product is a product innovation, and the new firm, if surveyed, would choose option 1 for Q2. This is still user innovation.

The consumer may share freely the knowledge gained in producing the new product with a peer group or a community of practice ${ }^{2}(3(b))$. This, according to the Oslo Manual, is not user innovation. Assuming the community of practice is not made up of firms, but of individual mountain bikers, kite surfers, kayakers, gardeners, or other such groups, there is no transfer to a market.

\footnotetext{
${ }^{2}$ While there are overlaps, a peer group here consists of other users of the technology or practice, while a community of practice consists of those who attempt to modify the technology or practice.
} 
In the final case, 4(b), the consumer keeps the knowledge. There is no transfer and there is no innovation.

\section{Thinking about the market}

In this section, a solution is proposed to the market requirement that excludes consumers that share freely with a community of practice the knowledge gained from their creating new or improved products. This is intended to start a discussion which may eventually influence the next revision of the Oslo Manual and admit this class of activity to that of user innovation.

The discussion then turns to public sector 'innovation' which also has a market problem if it is to be considered innovation according to the Oslo Manual definition. This is meant to broaden the discussion to include the considerable community of scholars and practitioners working on the subject.

\subsection{Broadening the Concept of User Innovation by Consumers}

The case that stands out in the analysis in the previous section is 2(c) where the consumer who created the knowledge of how to improve a product is not seen as an innovator, even though the knowledge has been freely and widely disseminated and others are able to use it.

This invites a review of paragraph 150 of the Oslo Manual. The paragraph addresses both product innovation and process innovation. As an individual is a consumer, but not a producer, the discussion of process innovation is not relevant. The individual consumer can only produce a new or significantly improved product, initially for own use. For this activity to be seen in official statistics, the consumer would have to transfer the knowledge to a firm that produces such products, or start a firm. In either case, the activity of innovation will be found in a business survey, not a social survey. Giving the knowledge to a peer group of individual consumers, or a community of practice, would not be seen in existing social surveys and were it seen, it would not be recognized as innovation.

To begin the analysis, consider the phrase 'when it is introduced on the market' and ask what this means. The innovation need only be introduced on the market; there is no expectation that the innovation will be purchased or adopted. The innovation could be an inexpensive cure for tuberculosis or an addictive narcotic. What is being described, for a product innovation, is the making available of the innovation to potential users of the product.

Consider a small revision of paragraph 150 .

A common feature of an innovation is that it must have been implemented. A new or improved product is implemented when it is made available to potential users. New processes, marketing methods or organizational methods are implemented when they are brought into actual use in the firm's operations. 
If this change is made, nothing in the application of the Oslo Manual is changed as far as firms are concerned. However, the consumers that develop or modify products to improve the benefits they derive become user innovators if they make the new or modified product available to potential users.

This requires some thought on what 'made available to potential users' means in practical terms. For a firm, this would still mean putting the product on the market. For the process innovator in the firm, this would apply to option 2(a), but for options 1(a) and 3(a), it is the knowledge that is transferred, not the actual process equipment or routines. In the case of the consumer as a user innovator, the same applies. For 2(b), a product is put on the market, but for 1(b) and 3(b), the knowledge is transferred in the form of blueprints or a prototype.

In the case of software, the knowledge is embedded in the product and there may be no distinction between product and codified knowledge if the user innovator provides a complete product in rows 1 and 3 of Table 1 . A more likely case would be that the user has improved a component of the product and provides that to the producer (row 1) or to the peer group (row 3). The second case is analogous to the transfer of blueprints or a prototype for a good or a detailed description of a service or set of routines.

For process innovation in a firm the market connection is through the product. A new or significantly improved process produces the product through a better transformation process or improved organization or use of better business practices. It could also deliver the product to the market in a better way or improve or develop markets to which the product is delivered. For public sector organizations, the same applies to process innovations but they are connecting to potential users through the product. Consumers are not process innovators.

If the revised version of paragraph 150 were accepted, the consumer would be a user innovator if the knowledge was shared with a community of practice, a peer group, or simply put on the web for all to see.

The objective of this subsection is to show that a small revision of paragraph 150 could include a class of consumers as user innovators. Of course, as mentioned in Table 1, a social survey would be required to find the population. This is an exercise in logic. However, it is understood that any actual revision of paragraph 150 is a matter for the OECD Working Party of National Experts on Science and Technology Indicators (NESTI), its parent Committee on Scientific and Technological Policy (CSTP) and the Statistics Committee. The suggestion here is to encourage debate in these and other forums.

If indicators, supported by codified knowledge in manuals, can be considered as equivalent to a technology (Gault 2011), with NESTI as the producer, the use of the modification to paragraph 150 in Finland could be an example of a user innovation.

\subsection{Public Sector Innovation}


There is another topic that could be influenced by a revision to the Oslo Manual definition and that is 'innovation' in the public sector. As with consumer innovation, there is a market issue. Public sector institutions are of two kinds, those that develop policy and those that implement policy and deliver services, such as education, government services, grants and contracts, and health care. In both cases, organizations can engage in all of the activities of innovation that are given in the Oslo Manual but, as with consumers, the result of the activities is not delivered to the market in all cases. Without that connection, the public sector innovation is not innovation as far as the Oslo Manual is concerned.

One of the motivations for studying public sector innovation and for producing indicators for monitoring and evaluating the activity are the financial constraints imposed by the 2007-2008 financial crisis and the subsequent expenditures on stimulus packages that now have to be paid back. This financial constraint is occurring at a time of rising healthcare costs in countries with aging populations, countries that are also trying to deal with environmental issues and sustainability. Doing more with less is an objective in these circumstances and innovation is a way to achieving it.

There have been studies of public sector innovation in the European Union (EU 2011), the UK government (www.hmg.gov.uk/publicsectorinnovation ) and at NESTA (Harris and Albury, 2009, Clark, Good and Simmonds, 2008, LSE Public Policy Group, 2008 and Mulgan 2007). A Nordic group (www.mepin.eu) has been working on the problem for several years (Bloch 2010a, b) and it has designed and conducted a pilot survey (Brugge, Mortensen and Bloch 2011). All of these initiatives link to work in progress at the OECD.

As the measurement work of the Nordic group is closest to that of the OECD and the CIS, it will be used for comparison. This starts with a comparison of the definition of innovation used in the Nordic Survey of Public Innovation 2009, compared to that of the Oslo Manual given in Section 4.1.

An innovation is the implementation of a significant change in the way your organization operates or in the products it provides. Innovations comprise new or significant changes to services and goods, operational processes, organizational methods, or the way your organization communicates with users (Brugge, Mortensen and Bloch 2011:74).

As with the Oslo Manual, there are three types of process, but they are not quite the same.

Table 2: Comparison of Olso and Nordic Process Activities

\begin{tabular}{|l|l|}
\hline Oslo - Business Sector & Nordic - Public Sector \\
\hline Process (transformation process) & Process (operational) \\
\hline Organizational process & Organizational process \\
\hline Marketing process & Communication process \\
\hline
\end{tabular}

The basic process, in both cases, deals with the transformation of inputs (energy, knowledge, material, and people) to outputs (goods, routines and services). The organization process is also the same in both cases. Only marketing and communication differ. The firm seeks new markets 
and acts to increase its presence in existing ones. The public sector organization informs users about the goods and services and methods that it offers, such as a new diagnostic tool in a hospital, a new curriculum in schools, or a new tax form that requires less effort to fill in.

In the definitions of product and process innovations in the public sector, products are 'introduced' while processes are ‘implemented'. For example:

A product innovation is the introduction of a service or good that is new or significantly improved compared to existing services or goods in your organization; and,

A process innovation is the implementation of a method for the production and provision of services and goods that is new or significantly improved compared to existing processes in your organization.

The structure of the process definition is similar for the other two processes with the exception that 'method' is qualified by the word 'new'. The process definition is also effectively the same as that of the Oslo Manual (para. 146 and para. 150).

The product innovation is 'introduced'. In the Oslo Manual, para. 150, “A new or improved product is implemented when it is introduced on the market", where the italics have been added. In the Nordic definition the new or significantly improved product is introduced to the product line, or made available.

The minor revision of paragraph 150 of the Oslo Manual, suggested in Section 5, could also accommodate public sector innovation. This is not to suggest that there should be only one manual dealing with innovation, but, as experience grows from measuring consumer innovation and public sector innovation, a next step could be the codification of the knowledge gained from each measurement activity in different manuals. The suggestion here is that this family of manuals have compatible definitions.

The Nordic Pilot Survey includes the follow-up questions Q1 for processes and Q2 for products. In principle these could be used to identify user innovation by public sector organizations for processes. As for the CIS, the question for products would have to be revised if consumers, as user innovators, were to be considered.

\section{Policy Implications of User Innovation}

User innovation is becoming more prevalent as a result of technology platforms and networking opportunities. Firms that have generated their knowledge for user innovation in their R\&D department are able, in many countries, to take advantage of R\&D subsidies. However, not all firms that innovate, either as users or producers, engage in $R \& D$, as defined in the Frascati Manual (OECD 2002), and most consumer user innovators do no R\&D.

If the identification and quantification of an innovation culture is a policy objective, there have to be other incentives to encourage user innovation. In addition to doing user innovation, there is 
the propensity of user innovators to share their knowledge freely and that raises questions about what policies would be appropriate to encourage this.

\subsection{Public Policies and Programmes}

Innovation is linked to economic growth and to enhanced productivity. In a competitive and global market, with an aging workforce in developed economies innovation supports the productivity driven economic growth that is needed, with fewer people in the workforce, to pay for growing healthcare costs, the repayment of interventions during the financial crisis, and other initiatives such as cleaner energy and better quality of life.

Innovation is at the centre of the EU 2020 Flagship Initiative (EU 2010), the OECD Innovation Strategy (OECD 2010a) and its measurement agenda (OECD 2010b) and, in the U.S., the Obama Innovation Strategy (Executive Office of the President 2009) has been renewed (Executive Office of the President 2011). There is no question about the perceived importance of innovation in the developed economies, but there is little in the innovation policies on the place of user innovation by firms or by consumers. An exception is Finland, where the role of consumers as user innovators is explicitly recognized (Ministry of Employment and the Economy 2010:31).

Both firms and consumers contribute to a culture of innovation which supports the generation of new knowledge and its conversion to value. If a culture of innovation is truly desirable, policy instruments, at the very least, should not get in the way of user innovators and at best, should offer some encouragement.

For firms, there are R\&D support programmes, but not all firms that innovate do R\&D (Gault 2010:60). However, there are other ways of encouraging user innovation. There are support programmes such as the Canadian Industrial Research Assistance Programme (IRAP), the German Fraunhofer Gesellschaft, the UK technology and innovation centres which is a similar programme to that of the Franhofer Gesellschaft, the UK Small Business Research Initiative (SBRI) and the U.S. Small Business Innovation Research (SBIR) programme. These programmes provide a mix of support mechanisms, expert technical advice and collaboration opportunities. There are also voucher schemes, such as those in the Canadian Province of Alberta, the Netherlands and the UK, where firms can apply for a voucher which allows them to purchase knowledge from institutions that help them to solve problems. Problem solving is a key part of user innovation.

For individual consumers that are innovating the incentive is the benefit derived from the innovation, the better product produced by the producer to which they may transfer their knowledge, the benefits of running their own firm if they chose to start a business or the recognition in their community of practice for having solved a problem of interest and having shared the results.

As the work cited in this paper shows, consumer innovation involves many people. They are part of a culture of innovation which could be supported by competitions, prizes and other forms of recognition. 


\subsection{Intellectual Property Law and Practice}

Baldwin and von Hippel (2010) review the economic benefits of the free revealing of knowledge resulting from user innovation and they also make suggestions for using intellectual property rights as a means of keeping innovation open as well as closed. These include support for 'open licensing' structures such as the Creative Commons License for writings and the General Public License for open source software code.

Baldwin and von Hippel (2010) make the point that design costs for innovation are falling and this is enabling single users as innovators. They are not supported by an institutionalized system for sharing as are participants in open collaborative innovation projects and the suggestion made is a procedure, similar to a patent disclosure, vetted for novelty by patent office examiners. This would allow innovators to add something to their curriculum vitae, like a patent but with free disclosure of the knowledge. They also suggest that in place of the benefit derived from the monopoly of a patent that the government offer a tax incentive for those who gain such documents to encourage free revealing.

The benefits of free revealing are well established in the software community and this work extends to analysis to the work of any user innovator that freely reveals the knowledge resulting from the innovation.

\section{Next Steps}

The next steps involve a wide discussion of the modification of the market component of the Oslo Manual definition of innovation and its implication for user innovation in official statistics initiated by consumers. Ultimately, this is a topic for the OECD Working Party of National Experts on Science and Technology Indicators (NESTI) which is responsible for revising the Oslo Manual. The Oslo Manual is a joint product of the OECD and Eurostat and the European Commission, including Eurostat, participates in NESTI.

To gain more information on user innovation in firms, there could be follow-up surveys in countries that have conducted CIS or CIS-like surveys. These surveys would confirm that respondents to option 1 of Q1 in Section 2 were user innovators, and to determine the extent to which respondents to option 2 were user innovators and to identify the other activities under that option. The follow-up surveys could also probe the activities covered by option 3. Similar follow-up questions could be added to surveys of use and planned use of technologies and practices as done for the Canadian survey (Schaan and Uhrbach 2009).

The follow up to CIS-like surveys has been done in Korea (Kim and Kim 2011) and is being done Mozambique (Zita and Lopes 2011). It has yet to be done in Europe, although there was an unfunded $7^{\text {th }}$ Framework proposal ${ }^{3}$ intended to cover this ground.

\footnotetext{
${ }^{3}$ The proposal was co-ordinated by Mark Knell, NIFU Nordic Institute for Studies in Innovation, Research and Education, Oslo, Norway.
} 
For information on consumers as user innovators to be gathered, there need to be questions added to existing social surveys or new surveys have to be initiated. As the statistics are published and compared internationally, the findings can contribute to policy evaluation and learning, leading to revised policies. Survey work in Finland, and the analysis of the data, building upon the NESTA work (Flowers et al. 2010) is part of this process. As the surveys and incentives evolve, questions could be added on the influence of incentives on user innovation among consumers.

All of this is in addition to the suggested work programme in Baldwin and von Hippel (2010) on incentives for user innovation and on the reform intellectual property law and practice.

\section{Acknowledgements}

The author wishes to acknowledge TEKES, the Finnish funding agency for Technology and Innovation, and the Finnish Ministry of Employment and the Economy for supporting the InFiProject to which this paper contributes. Jeroen de Jong, Jari Kuusisto and Eric von Hippel contributed to discussions in Finland and Carter Block provided information on the work of the Nordic group on public sector innovation.

\section{References}

Arundel, Anthony and Viki Sonntag (2001), Patterns of Advanced Manufacturing Technology (AMT) Use in Canadian Manufacturing: 1998 AMT Survey Results, Catalogue No. 88F00172001012, Ottawa: Statistics Canada.

Baldwin, Carliss and Eric von Hippel (2010), Modeling a Paradigm Shift: From Producer Innovation to User and Open Collaborative Innovation, Harvard Business School Finance Working Paper 10-038, MIT Sloan School of Management Working Paper No. 4764-09 (http://ssrn.com/abstract=1502864).

Bloch, Carter (2010a), Measuring Pubic Innovation in the Nordic Countries: Final Report, Aarhus: The Danish Centre for Studies in Research and Research Policy.

Bloch, Carter (2010b), Towards a Conceptual Framework for Measuring Public Sector Innovation, Module 1 - Conceptual Framework, Aarhus: The Danish Centre for Studies in Research and Research Policy.

Brugge, Markus M., Peter S. Mortensen and Carter Bloch (2011), Measuring Public Innovation in Nordic Countries: Report on the Nordic Pilot Studies - Analysis of Methodology and Results, Aarhus: The Danish Centre for Studies in Research and Research Policy. 
Clark, John, Barbara Good and Paul Simmonds (2008), Innovation in the Public and Third Sectors, Innovation Index Working Paper: September 2008, London: NESTA.

De Jong, J.P.E. and Eric von Hippel (2009), 'Transfers of User Process Innovation to Process Equipment Producers: A Study of Dutch High-Tech Firms’, Research Policy 38(7), 1181-1191.

Executive Office of the President (2009), A Strategy for American Innovation: Driving Towards Sustainable Growth and Quality Jobs, Washington, DC: Executive Office of the President/NEC/OSTP.

Executive Office of the President (2011), Strategy for American Innovation, Washington, DC: Executive Office of the President/NEC/OSTP.

EU (2010), Europe 2020 Flagship Initiative, Innovation Union, SEC(2010) 1161, COM(2010) 546 final, Brussels: European Union.

EU (2011), Innobarometer 2010, Analytical Report, Innovation in Public Administration, Flash EB No. 305, 2010 Innobarometer, Brussels: DG Enterprise and Industry (http://ec.europa.eu/public_opinion/flash/fl_305_en.pdf).

Flowers, Stephen, Eric von Hippel, Jeroen de Jong and Tanja Siozic (2010), Measuring user innovation in the UK: The Importance of Product Creation by Users, London: NESTA

Gault, Fred and Eric von Hippel (2009), The Prevalence of User Innovation and Free Innovation Transfers: Implications for Statistical Indicators and Innovation Policy, MIT Sloan School of Management Working Paper No. 4722-09, Cambridge, MA: MIT.

(http://ssrn.com/abstract=1337232)

Gault, Fred (2010), Innovation Strategies for a Global Economy, Development, Implementation, Measurement and Management, Cheltenham: Edward Elgar and Ottawa: IDRC.

Gault, Fred (2011), Social Impacts of the Development of Science, Technology and Innovation Indicators, UNU-MERIT Working Paper 2011-008, Maastricht: UNU-MERIT (www.merit.unu.edu/publications/wppdf/2011/wp2011-008.pdf).

Greene, Lucie (2011), The 'in' crowd, The Financial Times, February 12/February 13, 2011 p. 6, London: Financial Times.

Harris, Michael and David Albury (2009), Why Radical Innovation is Needed to Reinvent Public Services for the Recession and Beyond, The Innovation Imperative, The Lab Discussion Paper: March 2009, London: NESTA.

Kim, Youngbae and Hyunho Kim (2011), User innovation in Korean Manufacturing Firms: Incidence and Protection, KAIST Business School Working Paper Series KCB-WP-2011-01, Seoul: KAIST Business School. 
LSE Public Policy Group (2008), Innovation in Government Organizations, Public Sector Agencies and Public Service NGOs, Innovation Index Working Paper: September 2008, London: NESTA.

Ministry of Employment and the Economy (2010), Demand and User-Driven Innovation Policy, Helsinki: Ministry of Employment and the Economy.

Mulgan, Geoff (2007), Ready or Not?: Taking Innovation in the Public Sector Seriously, Provocation 03, April 2007, London: NESTA.

OECD (2002), Frascati Manual: Proposed Standard Practices for Surveys on Research and Experimental Development, Paris: OECD.

OECD (2010a) The OECD Innovation Strategy, Getting a Head Start on Tomorrow, Paris: OECD.

OECD (2010b), Measuring Innovation, A New Perspective, Paris: OECD.

OECD/Eurostat (2005) Oslo Manual - Guidelines for Collecting and Interpreting Innovation Data, Paris: OECD.

Ogawa, Susumu and Frank T. Piller (2006), “Reducing the Risks of New Product Development”, MIT Sloan Management Review, vol. 47, no. 2, 65-71.

Schaan, Susan and Mark Uhrbach (2009), Measuring User Innovation in Canadian Manufacturing, 2007, Catalogue No. 88F0062009003, Ottawa: Statistics Canada.

Statistics Canada (2008a), Survey of Advanced Technology 2007, The Daily, June 26, 2008, Ottawa: Statistics Canada.

Statistics Canada (2008b), Follow-Up to the Survey of Advanced Technology 2007, The Daily, October 27, 2008, Ottawa: Statistics Canada.

Statistics Canada (2010), Survey of Innovation and Business Strategy 2009, The Daily, November 22, 2010, Ottawa: Statistics Canada.

Uhrbach, Mark (2009), Innovation in the Canadian Manufacturing Sector: Results from the Survey of Innovation 2005, Catalogue No. 88F0062009002, Ottawa: Statistics Canada.

von Hippel, Eric, Jeroen de Jong and Stephen Flowers (2010), Comparing Business and Household Sector Innovation in Consumer Products: Findings from a Representative Study in the UK, (SSRN: http://ssrn.com/abstract=1683503).

von Hippel, Eric (1988), The Sources of Innovation, New York: Oxford University Press. 
von Hippel, Eric (2006), Democratizing Innovation, Cambridge MA: The MIT Press.

Zita, Julia and Avelino Lopes (2011), User Innovation in the Mozambican Business Enterprise Sector for Maputo Province: Presence of User Innovation, Working Paper, Maputo: Ministry of Science and Technology. 


\section{The UNU-MERIT WORKING Paper Series}

2011-01 Mitigating 'anticommons' harms to research in science and technology by Paul A. David

2011-02 Telemedicine and primary health: the virtual doctor project Zambia by Evans Mupela, Paul Mustard and Huw Jones

2011-03 Russia's emerging multinational companies amidst the global economic crisis by Sergey Filippov

2011-04 Assessment of Gender Gap in Sudan by Samia Satti Osman Mohamed Nour 2011-05 Assessment of Effectiveness of China Aid in Financing Development in Sudan by Samia Satti Osman Mohamed Nour

2011-06 Assessment of the Impacts of Oil: Opportunities and Challenges for Economic Development in Sudan by Samia Satti Osman Mohamed Nour

2011-07 Labour Market and Unemployment in Sudan by Samia Satti Osman Mohamed Nour 2011-08 Social impacts of the development of science, technology and innovation indicators by Fred Gault

2011-09 User innovation and the market by Fred Gault 